Article

\title{
Sustainable Geographical Changes in Rural Areas: Key Paths, Orientations and Limits
}

\author{
Angel Paniagua
}

check for updates

Citation: Paniagua, A. Sustainable Geographical Changes in Rural Areas: Key Paths, Orientations and Limits. Sustainability 2021, 13, 2059.

https://doi.org/10.3390/su13042059

Academic Editor: Luca Salvati

Received: 27 January 2021

Accepted: 6 February 2021

Published: 14 February 2021

Publisher's Note: MDPI stays neutral with regard to jurisdictional claims in published maps and institutional affiliations.
Spanish Council for Scientific Research, CSIC, 28037 Madrid, Spain; angel.paniagua@csic.es

\begin{abstract}
Rural differentiation processes have formed the backbone of rural studies. Owing to the strength of rural-urban and local-global relationships, the theoretical approaches to rural restructuring in the Anglo-Saxon world and new rurality in Latin America only have a limited capacity to explain contemporary global phenomena of rural spaces. Due to this, transverse theoretical and methodological approaches have emerged to explain social, environmental and spatial (rural) processes. Here, a new approach is proposed called the individual-global field, based on the individual-global binary category to substitute the traditional relevance of the locality-communityglobality association This new approach tries to reinvigorate rural geography in a more flexible way, based on minor theory, to adapt to all the phenomena that can occur globally. In any case, various spatial planes are proposed, dominated by specific socioeconomic processes on which the rural individual would move.
\end{abstract}

Keywords: rural geography; rural restructuring; individual dimension; binary relations; rurality; globality

\section{Introduction}

Perhaps more than any other discipline, the evolution of rural geography has been marked by the appearance of new study tendencies that have been added to the previous ones, gradually broadening both conceptual and methodological orientations. This tendency, a constant in the history of new rural geography, has greatly increased since the so-called cultural shift in rural geography (Anglo-Saxon) at the start of the 1990s of the last century. Some recent reviews clearly show the continuity of this academic approach to date [1-3]. The establishment of these changes, or new methodologies, as well as expanding approaches of rural geography, follows rhythms of diffusion, acceptance and implementation that vary greatly among the different national geographic schools. Hence, nowadays, in addition to there being a wide repertoire of approaches, in a global consideration of the discipline [2], these are implemented to variable degrees in the different settings, international areas or national schools. Several decades ago, the geographer Robinson [4] described rural geography as somewhat anarchic. More recently, Professor Woods [5] has acknowledged a relative fragmentation and deficient integration of rural geography as a subdiscipline. Nowadays, this situation is even more complex for two reasons: (1) the numerous studies of rural (and urban) areas from the different subdisciplines (e.g., geography of population, services, social geography, cultural geography, etc.), which affect different aspects of rural spaces; (2) the ambivalent relationship between rural geography and rural studies, which essentially integrates rural geography and sociology and some areas of rural economy or agriculture.

Two tendencies currently coexist in human geography: (1) on the one hand, a concern for specialization that leads to the invention of successive geographies on the basis of physically recognized fields of research, which divide research objects in a dichotomous or binary way; (2) on the other hand there is a concern to integrate and synthesize to achieve or preserve a unity within the geography. These trends are reproduced in rural geography, 
given that there is an understandable concern about the future of rural geographical studies owing to the existence of two, apparently opposing, tendencies:

(1) A clear fragmentation of tendencies or approaches that generate the internal discussion that has historically favored progress in rural geography. This debate is essentially based on rurality [3] and currently continues as a form of social context or division of labor, or as a category defined for social purposes, land use, etc. [6]. Basically, it gives rise to social and economic restructuring processes of rural areas and their implications in the theoretical progress of the discipline [7]. The study of rurality takes place along several different pathways: economic policy, social approach, cultural approach and the moral perspective, in addition to some other less important shifts or tendencies in rural geography. Ultimately, all of them aim to analyze the rurality, or different areas of rurality [3]. Paradoxically, this fragmentation coexists with an interpretive tendency towards a global rural world [5,8,9]—a globalized rural world and a fragmented rural geography. One may also wonder whether current attempts to describe and analyze globalization processes perhaps imply the need to create a globalized rural geography. There is a recognized fragmentation between the developing and developed worlds, with a predominance of Anglo-Saxon rural geography [10]. Would it be possible to create a global rural geography? Only if rural geography is to be understood as the academic (sub) discipline capable of uniting an increasingly global and complex rural world in a single debate.

(2) Dilution (of the limits) of the discipline among the other scientific disciplines and subdisciplines through rural studies and transversal approaches to rural areas. In 1999, Professor Robinson [4] proposed that rural studies covered three main areas: geography, sociology and the economy. The most recent advances in rural studies at an international level have reinforced this tendency: with a large number of studies on rural spaces presenting theoretical frameworks and transversal methodologies, applicable to any kind of rural, non-rural space. Moreover, the evolution of studies of a place has increased the hybrid approaches in social disciplines, mainly in anthropology, sociology, or even in geography itself [11,12]. These approaches all have clear consequences: the removal of rurality as the central focus of rural spaces. Numerous studies published in international journals, such as Population, Space and Place, Journal of Rural Studies or Land Use Policy, show this tendency. They, also, reinforce the transversality, emphasizing the environmental, cultural and populational, rather than the strictly rural methodologies. In recent progress reports on rural geography, e.g., Woods [7], many of the references used are not geographical and fuel a tendency used previously in the discipline during the seventies: definition of the object of the (rural) geography through diverse themes.

It could, probably, be argued that these trends and concerns also arise in other disciplines such as urban geography [13]. However, owing to the concentrated nature of urban geography, of the place that it analyzes, this has veered towards system's analysis of urban places and the study of individual cities and towns [14], and globalization processes have been studied from these two perspectives. However, because of the disperse nature of rural spaces, they cannot be analyzed in the same way. From a perspective of the political economy, it has been necessary to adapt the thesis of the unequal development of space to the rural space [15], and since then, urban-rural has been one of the most characteristic binaries.

Today, rural geography seems to be involved in a circular debate where arguments associated with local-global binary relations and the power of the community are reiterated, where the focus on rurality is an obstacle to progress in the discipline. If cultural and ethical approaches aim to overcome the limitations of the political economy in the study of rurality, these currently appear to have entered a phase of relative exhaustion [1]. In addition, to go beyond the political economy or social representation $[2,3]$ would entail certain risks for a globalizing rural geography. 
Faced with this situation of fragmentation and the relative exhaustion of rurality as central to advances in rural geography, can we suggest other alternatives? The evolution of rural geography has reinforced the binary relations in the study of rurality [16], in a dialectic manner between countryside and city, locality and globality, production and consumerism, etc., seeking the differentiation of rurality [17]. Surely the permanent search for a differentiated but changing rurality would condition the progress of the discipline [18]. This situation has continued with the sociocultural approach, which does not generate works of sufficient length to reflect the progress of rural geography, leading to an academic crossroads [1], and limiting the theoretical advancement of the discipline. This problem is not only present in northern perspectives in rural geography but also from the south. However, that rural geography had hitherto been a fairly original sub-discipline (as had rural economics and rural sociology) as long as the city and the countryside were fairly separate, but these days, the countryside differs less from the city in a social sense. Another academic focus is needed. This paper proposes an alternative to the aforementioned limitations of rurality in the development of rural geography $[1,3]$, which extends beyond the binary concept of rural space. This, instead, is founded on the (spatial) power of the individual and how he daily organizes his life in relation to postmodern spatial planes, characteristic of a global countryside. This perspective also favors construction of a global rural geography (with the North and the South).

In any case, to reach this point of exhaustion and expansion it is important to explain the recent itinerary of rural geography, especially by means of its most recent debates. For this purpose, we can consider two representative and relatively autonomous sources: one associated with the Global North based on the British and Anglo-Saxon literature, and another linked with the Global South, illustrated by the Latin American case study.

Consequently, the goal of this paper, and of this trajectory along two foci representing the Global North and the Global South, is to demonstrate, in addition to the academic fragmentation and the different rates of this: (1) the current exhaustion of rurality as a basic study focus-derived from the limitations of the social constructivist approach [3] and (2) some binary categories, such as local-global, typical of rural studies. The repeated and fragmented use of these concepts and approaches has led to a difficult crossroads [1] or to a standstill for rural studies of a more geographical orientation. Therefore, other approaches are required that can amalgamate a rural geography that goes beyond rurality and the more traditional binary approach. Rurality as a central component of rural studies can be complemented by other planes, which are usually more transversal and tend to oscillate not between locality-community, as the most common binary category in rural studies, but between the individual and globality. These planes, linked to governance (rural), the environmental and the ethnic, would reduce the importance currently given to the study of rurality. We, therefore, suggest a more individual approach, by means of multiple spatial planes, representative of a postmodern rural geography, in which rurality is no longer the core (essential) part of the study.

The methodological argument to demonstrate the goals of this paper is the selection of two great geographical areas with academic global conceptualizations to explain and analyze the specificity of rurality (Anglo-Saxon debate and Latin-American debate). The globality of rurality has had regional schools in the Global North and Global South within the rural studies of a geographical nature. Once the insufficiencies in both schools have been confirmed, a more flexible approach based on the daily life of people living in rural areas is proposed, which can be used for any rural part of the world.

\section{Rural Restructuring in the Global North (Anglo-Saxon)-Elements for Debate}

In the seventies, studies of rurality began to appear with the purpose of systematically defining urban and rural realities [19]. After this, two itineraries were established: (1) the link to the political economy and (2) association to sociocultural analysis In any case, the debate on rurality has a strong influence on the development of recent rural geography [1] During the nineties, a series of approaches crystallized within rural geography that coexist 
to date and which, ultimately, provide the inheritance for the discipline: the political economy, social orientation, cultural orientation, moral orientation, scenic-regionalist orientation and the renewed geography of agriculture. Each tendency follows its own approach to rurality and advances along its own pathway. Undoubtedly, this reinforcement strengthens, but also weakens, the discipline, as it generates partial debates which together have only a limited influence.

The first debate: Rurality from the political economy approach Application of the political economy implied the acceptance of a degree of specificity of the rural in processes of global socioeconomic change. In other words, some rural global socioeconomic processes crystalized locally. The development of this, as well as different social and spatial assumptions, has constituted a clear cornerstone of rural analysis, almost until the present day, and has significantly conditioned (and limited) the rural debate. From this perspective, processes of global change can be expressed differently in each rural area. In other words, there is an (inter)action of global processes and local structures. This viewpoint leads to the configuration of distinct product zones [20]. The interaction of political, economic, cultural and demographic global processes generates a gallery of rural spaces, from those more closely based on conservation to others more linked to production [18].

The book by Neil Smith [21], Uneven Development, suggests that the "capital inherits a geographical world that is already differentiated into complex spatial patterns" [21] (p. 135) On the whole, the uneven development of capitalism entails a different and unequal growth among the economic sectors, social classes, processes and geographical areas at different spatial scales. Production of space under capitalism is traditionally considered to generate three scales: urban space, national space and global space. Rural space does not, explicitly, appear as a spatial product or scale [22]. Hence, uneven development suggests an urban perspective. Rurality is reduced to, or associated with, a professional category, or the farming sector $[16,22]$. The agricultural issue in political economy is linked to the "spatial focus" at three levels [23]: the very distinctive nature of agricultural production, associations between non-farm agents in the food system and survival, at a micro-level, of the farms. Hence, in this way the political economy promotes among rural geographers the debate and concern about the influence of global processes in rural localities [15], as the main binary category [18], through four different processes: economic (structure of the local economy and relationships with the major economic processes); social (demographic changes and models of social change); political (organization of local policies and participation in processes of development); cultural (community identity). The processes of rural change will, therefore, be multidimensional [24]. The (individual) repercussion of these global processes in the field favors a differential measure and analysis of the rurality. The way in which these global processes interact in each community or locality will lead to four basic types of countryside: the preserved countryside, dominated by consumer activities and by the rural idyll; the contested countryside, resulting from a heterogeneous society with different perspectives on land use; the paternalistic countryside, associated with areas predominated by large properties; the clientelist countryside, associated with the more remote rural areas [25]. The classical approach, from the political economy, is more concerned with describing products or final spaces than with analyzing the global processes that produce them.

Rural restructuring gives great relevance to the rural locality, as it reveals that the peculiarities of each place are produced by a single and historical chain of social and economic changes [26]. The localities are not studied for themselves, but as laboratories of processes of rural change. A set of new binomial dialectics crystallizes in the locality arising from globalization [16] and would produce type localities ranging from "powerful localities" to "dependent localities" [16]. This approach has revitalized studies on the community from three perspectives: (1) the community as a territory; (2) the community as a social system linked to the structured social relationships that take place inside a locality; (3) the community as an identity [26]. It is important to insist that the local setting be considered as central in rural restructuring activities. This occurs by joining together 
locality and rurality to form the rural locality, where global processes converge. To do this, the locality must be considered again as a "meeting point" [25].

This approach has had several points of replication, which can be synthesized into two major alternative positions: (1) the difficulty of isolating processes of general socioeconomic transformation from specific ones for rural areas. Basically, these global processes would not be exclusive to rural or urban areas but would have a transversal character for both of them $[27,28]$. Rural restructuring constitutes an approach to the study of rural space and not an interpretation of it [20,29]. (2) The influence of Kausky [30] book, Agrarian Question lays the foundations for an alternative point of view based on the resistance of agriculture to the objective, rational (and industrial) capitalist process and the resistance strategies of the farmers to global processes [31].

Rurality differentiated from the perspective of the political economy is renowned for endeavoring to create an articulated proposal for the analysis of rural areas anywhere in the world. However, the examples used to systematize this proposal are based on a highly evolved rural space: the British one [18], and not on other less-transformed rural spaces. Moreover, several questions come to mind that reflect how global processes are described and addressed in specific areas: What is a global process? How does it become a specific one? What are the channels, and how are they articulated? Finally, and most importantly-What are rural global processes, and how are they characterized and personalized compared to urban ones? The difficulty of giving a suitable and universal (or global) answer to all these questions leads to a degree of exhaustion of academic approaches. This has, also, resulted in a certain deterioration and distortion in the use of rural restructuring, converting it into a perspective of work [20].

The limitations of political economy for studying rural spaces can be summarized in: (1) A standardizing of the analysis of space concealing singularities and nuances; (2) Amalgamation of the local perspective (in relation to the global in its political-economic dimension), the community (as a social aspect), and the place (as a space) generating specific spaces that react in a homogeneous way to global processes. In other words, to a large extent, the political economy is based on an-perfect-articulation between community, locality and place; (3) A study of in-depth rurality and the specificity of strictly rural socioeconomic processes, resulting in a clear urban-rural differentiation.

The recent attention paid to the global sphere raises new questions and areas of work. Globalization is a theme that has appeared previously in rural geography but is also a tendency that leads one to reflect about whether a global countryside can exist, and consequently a global rural geography, with common explanatory frameworks for all types of rural spaces. Certainly, Professor Woods [5] emphasizes this aspect and indicates the unlikelihood of finding a global rural equivalent to the global city. In this regard, he lists ten characteristics that an ideal global countryside should fulfill [5], which would be partially manifest in each place. In other words, the global countryside is not articulated homogeneously and is shown in a different manner in each place $[5,17]$.

The interpretative tendency of a globalized rural world $[5,8]$ emphasizes the different global processes that act (not exclusively) upon rural areas, revitalizing the globalizationlocality duality. In contrast to previous ones, this new approach shows the characteristics of a (new) global field that aspires to cover both the developed and the developing worlds [5], an articulated approach that would adopt a differential nuance in (rural) places [32]. The acceleration of globalization processes in the Global North and the Global South would entail the same changes, but with different scales, intensity and temporality [10]. In this way, we would be regressing towards a differentiated geography of the global field [5] (p. 497) that would emphasize the-differentiated — exposure to global processes or characteristics and would manifest in the place through material and discursive relationships. In recent publications, some global processes are described insistently as: the international mobility of rural people between the Global South and the Global North and between the urban areas and the rural spaces, associated with differentiated processes of gentrification and counter-urbanization $[8,33,34]$, the global areas as a space of opportunity for progress in 
individual biography [33,35]; rural areas as a key spaces for food security and to control global climate change processes $[7,8]$. The political economy has focused on analyzing the locality as a means of researching global processes. By contrast, less emphasis has been placed on the global explanation of rural spaces and its (differentiated) connection to each local (rural) space. The description of global processes is noteworthy for it is exhaustive [25]. Is something missing when these global processes are described in the framework of rural restructuring? We can see that such an exhaustive consideration of global processes serves the combined strategy at a local level. Hence, because of the emphasis on the local laboratory [26], global processes have not been sufficiently described.

Therefore, the binomial relationship or dialectics that have dominated the geographical literature since more than 20 years ago with the political economy would still be manifest [16]. The key issue is that every global process has a specific local manifestation, with a geographical dimension. It goes on to describe global processes, but not connected, articulated or manifest in each rural locality. In this respect, there has been little progress in rural geography over the past twenty years. This continuous ambiguity suggests that any rural place can be a product of the specific combination of different global processes, with an infinite number of nuances. However, the specific connection and articulation between global processes and rural locality has been a continuous characteristic of the political economy without being openly evident. Before, emphasis was placed on rural locality and now it is placed on rural globality. Both can have a wide interpretative margin, resulting from the spatial combination usually present in political economy, but never accurately defined. What does global really mean? It can be understood from different perspectives. Globalization is a theme (global countryside), a tendency and also may refer to a global rural geography. The global countryside is more associated with global processes than with final spatial products. In other words, the globalization debate emphasizes the local and global spheres, at the expense of focusing on the connection between them, and the link between local and global is largely unexplored in its true roots, articulations and connections.

The second debate: Rurality from the sociocultural turn. An alternative perspective to the political economy would be associated with culturally based rural studies. The meaning of rural, as well as its contents, is interpreted through different lifestyles or types of life. With studies based on culture, the complexity of the analytical tendencies in rural studies is extended. Culture can be understood in terms of a greater plurality of interpretative routes or frameworks. Both dimensions can be acceptable: on the one hand, there is an evolution from the functional to the cultural and from there to the ethical, and also an analytical coexistence of the functional, the political economy and sociocultural tendencies [36]. The cultural angle rearticulates and also enriches the debate on rurality, by permitting the creation of new frameworks and analytical contexts and helps to increase the field of study of Rural Geography [37].

The collective book of Professor Cloke et al. [38]—Writing the Rural. Five Cultural Geographies-suggests that rurality has been the target of cultural analysis because of rapid changes in these areas and the significant number of publications that idealize the rural [36]. Cloke and Thrift [36] describe four phases in the conceptualization of rurality: (1) of a functionalist nature; (2) from the perspective of the political economy and its debate concerning the locality; (3) through multiple overlapping social spaces; (4) the current one linked to the post-structuralist deconstruction of rural discourses. As Halfacree indicates [39], it is important to distinguish between sign (the rural) and significance (multiple meanings) when proposing that rurality moves away from its multiple meanings. Symbolization also entails simplification and enrichment [40]. This stance is embodied in the locality. From a sociocultural interpretation, the locality still reflects one of the classical binomial relationships of rural geography: locality-globality.

There has been an important debate on the sociocultural interpretation of local-global connections. It has been suggested that different popular discourses can exist inside and outside the rural [41]; or different discourses can exist depending on the geographical 
scale [42]; or that these discourses vary in relation to the condition of class, race and gender, in relation to nature or the scenery, consideration of the community, or the opposition between city and village. In any case, it is associated with somewhat repetitive models linked to a certain theoretical approach and binomial methodology. There is also a foundation that characterizes the political economy through the rurality_since Halfacree [39]—initially in a binomial manner. Through the representation of rurality, progress can be made into the possibilities of dual approaches that characterize works of political economy [1,43-45]. Some more sophisticated studies [46] introduce an everyday-spontaneous-dimension more closely associated with the individual but connected to a formal dimension of rurality and rural locality. The combination of these three elements produces variants in the definition of rurality, which are not completely independent of the political-economic heritage.

There can be considered to be two facets to the controversy about rurality in the context of its cultural dimension: (a) its alternative nature in relation to the establishment of strict and topographical limits of the rural; (b) the representation of rurality associated with a plural view of the rural society, where each social group can generate its own spatial representation [46,47]. Common criticisms of these kinds of approaches are based on their poor operativity outside academia and the relative non-existence of global or general analytical categories.

Currently, we could say that we have reached a crossroads: (1) one way leading towards a moral and ethical dimension of rurality and affectivity, and the rural emotion [48, 49]; (2) a certain (re)materialization of rural studies [1,50]. However, these show rurality from the Anglo-Saxon perspective and mark the main international tendencies. Recent works acknowledge the limitations to developing an international rural geography based on contributions outside tendencies that dominate in the Global South [51,52]. This is why it is interesting to also consider the debate of rurality from rural studies in Latin America-a debate more closely based on rural studies than on Latin American rural geography itself.

\section{The New Rurality in Latin America-A Complex Perspective from the Global South}

From Latin America, what panorama can we envisage that could serve Europe (or part of it) and part of the non-European Anglo-Saxon world? This problem is not easy to solve given the great difference in the academic traditions. Rural studies, especially geographical ones in Latin America, do not follow one homogeneous tendency. Until the 1970s they were associated with sociospatial descriptive models. After this decade, the studies focused more on the repercussions of international economic transformations in rural studies, the complexities of agroindustrial production, and the ways of capitalist penetration in traditional farming societies, in addition to numerous studies on the rural population. Due to the strength of these debates and the delayed articulation of national schools, it was some time before themes that could help establish a parallelism with Europe appeared: debates about the rural space and the role of the State, governed by the political economy. In addition, with some delay, quantitative approaches to the study of the rural appeared $[53,54]$, which were not exempt of contributions from a social approach. After this stage, it is necessary to refer to the so-called New Rurality in Latin America. The new rurality is, in general terms, an adapted mirror of the academic tendencies of the Global North. Some characteristics of the new rurality make it comparable to the main tendencies in Europe (the Anglo-Saxon focus), since the intention is to generate an argument that is valid for the whole of Latin America. Professor Llambí [55] suggested that the new rurality constituted an umbrella concept for the transformation taking place in rural spaces in the 1980s at the end of the last century, which prevailed over the traditional dichotomy of urban (equals modernity) and rural (equals traditional and farming). This also entailed the transition from a more sectorial focus to a more pluralistic one.

This new approach mainly has a territorial, significantly heterogeneous, dimension, composed of the following phenomena: a rise in non-farming occupations in the countryside; birth of the transnational community of rural migrants; a change in farming life due to the new technologies; concern in the research agenda for issues related to social 
inequality, poverty and marginalization; gender and ethnic issues related to the peasant community; conservation of the environment. These issues have been studied via two different approaches, often applied to the same phenomena: (1) the first associated with the political economy and (2) the second of a more social nature.

The first debate: The political economy approach is more focused on territorial phenomena. One of the main goals of this argumentative context is to distinguish the rural from the urban throughout the Latin American space, and implicitly aims to develop a singly notion of rurality for Latin America. This new rurality incorporates modern components, in contrast to another traditional rurality. The types of farming and their insertion in the global setting would largely determine this traditional way of understanding rurality [55-58]. Owing to the reduced importance of agricultural activity, it is important to review the relationship between rural and urban to renew the conceptualization of the peasant [59]. In the new rurality, the peasant and traditional rural actors gradually disappear under the tendencies of globalization that consolidate a global system of agriculture. However, this process has different territorial expressions, so is consequently heterogeneous and of variable intensity [60].

However, is it possible to understand such diverse realities within a single analytical framework, such as those contemplated in the north of Mexico to the south of Argentina? The idea of addressing all the dimensions of a rurality from only one line of reasoning is a significant limitation when endeavoring to explain complex and often very different realities. Some analysts [61] have argued that the farming question, perhaps one of the most important issues of the political economy, cannot be described in any single way, owing to its very varied forms and circumstances.

Some empirical contributions seem to corroborate this line of reasoning in the context of new politics and rural democracy: the studies in these different areas of Mexico by Fox, García and Haight [62] and Otero [63], and also in Brasil [64], by means of lines of thinking for the whole of Latin America [65], or linked to interpretations of transnational social rural movements in Latin America [66]. These studies emphasize the complex and multiple trajectories at a citizen-individual farming-rural level [67]. The addition of all the individual responses in each area generates a combined response to different restructuring processes. We must understand that these processes have a more qualitative than quantitative basis. As Kay suggests [68], many individuals and homes in these areas find a way to overcome their deficient living conditions only by overcoming the binomial differentiation of urban-rural [69-71]. This especially occurs within the context of an accepted surge in the non-farming rural economy, which establishes a flexible relationship with the urban world and other transnational spheres [72,73]. This perspective is also sustained by Wood and Bryan [74]. As Escobar proposes [75], the concept of one simple idea of modernity would be replaced by a group of modernities. This line of reasoning is very interesting as it recognizes multiple trajectories, which conjugate different axes, planes and scales, where reality is established within a context of permanent instability. This takes us far away from the concept of one single explanatory context for large spaces. In other words, multiple realities and expectations can live together in a single space.

What was distinctive in the application of political economy in Latin America? Basically, the repercussions of international economic transformations in rural studies, the complexities of agroindustrial production and the-external-ways of capitalist penetration in traditional farming societies. The strength of these debates delays the incorporation of issues associated with the Global North: the debate about rural space and the role of the state.

The debate on rural space equates the new rurality to an (open) list of (new) phenomena of dimensions or territorial manifestations, without attempting to construct a closed explanatory model. Rural territory can be understood as a product of social relations. Moreover, it is determined by the expansion of social relationships characteristic of the countryside [76]. The new rurality, seen from political economics, incorporates a spatial perspective that surpasses the traditional sectorial approach. Changes in rural spaces are 
expressions of globalization, but also of the responses and the resistances of the territory and the social agents [60].

The second debate: The social focus of the new rurality is based on a combination of the individual social relationships of the rural community. The new rurality is an alternative for the communities, in their aspirations to improve their own living conditions and social organization in relation to globalization processes [77]. The rural space is determined by the size of its characteristic social relationships and rurality does not have precise geographical limits [76]. The rural space would contain a new set of activities that favor the appearance of a plural society [78]. Heterogeneity is an intrinsic characteristic of the rural community in Latin American spaces and is reproduced through new rural activities. As Riella and Mascheroni suggest [79], the new rurality refers to the existence of nonfarming rural activities. For these authors, new or old does not mean pronounced or major transformations, but rather new social realities often not previously contemplated. The new non-farming space or rural territory must be linked to the emergence or crystallization of new social dynamics [80]. New activities, new spaces, new societies or microsocieties would be implicitly linked [81]. In this way, the new Latin American rurality shares some similarities-although occurring later on-with the rural restructuring in Europe, and also some of its more evident limitations. The main differences arise from the complex of new (social) relations characteristic of the rural community that are fundamental to the definition of the new rurality, based on (open) lists of new activities, but with a common territorial dimension. This community perspective of the new rurality assigns the rural inhabitants a role of their own in overcoming poverty and exclusion, by means of increased autonomy, productive diversification and management of the natural and cultural resources by the community [77]. From this perspective, the changes associated with globalization processes would also constitute an opportunity for change for the community [82].

The cultural shift in rural geography is less important in Latin America than in Europe, due to the relevance of strictly social and territorial approaches. Moreover, more cultural approaches reproduce some of the weaknesses that have been seen in Europe: its excessive microcharacter and its link to the ad-hoc reality they study. However, they are relevant for the study of associations or fractures between the countryside and the city, the creation of new activities and the ethnic question at different spatial scales [83].

There are two main different sources of problems in the new Latin American rurality:

(1) Insertion of the spatial or territorial plane in the socio-community plane, such as in Europe; processes of spatial differentiation cannot be clearly articulated outside the urban-rural differentiation. The rural specificity is articulated into different ruralities. Different socio-community relationships based on differentiated rural spaces in relation to urban-rural and global-local processes, which characterize the theoretical assumptions of the new rurality or rural restructuring. The interaction between the urban-rural dialectics is articulated with the global-local dialectics via labor mobility and the creation of new activities. Global processes are concentrated in small, remote localities (far from the cities) [84], occasionally by the creation of refuge spaces for small indigenous and peasant populations [85]. The rural locality is still relevant.

(2) The design of a common Latin American rurality. This has been acknowledged by some authors, such as [86], and could also be a point of comparison with the rurality debate in Europe. We may then ask ourselves: What is characteristic of the new rurality for the whole of Latin America, and what is the specificity of the new rurality in each country? In other words, what can the rurality of each country contribute to a Latin American rurality? The new Latin American rurality is not based on a clear theoretical arsenal that integrates sociopolitical and socioeconomic processes as intended in Europe, but instead pivots on the declaration of lists of changes or transformations, grouped together or not, which in some way were-or are-common to the Latin American space to a greater or lesser extent. Due to this, no clear conceptualization appears of Latin American rurality, since many of these transformations of different 
formulation, presentation and intensity could appear in other parts of the world, even in some of the European countries of slower modernization.

Hence, with different trajectories and problems, the new rurality shares a similar problem to restructuring in Europe: the problem of a robust and complex definition.

Professors Cloke [1] and Woods [3] are taking global rural geography along an interesting path, the positionality of the rural researcher [3] or the minor theory [1]. In both cases, they suggest approaching the everyday life, or rurality performed by rural residents, from multiple sources. The two ways are thought-provoking proposals for a way forwards in a flexible rural geography that can be adapted to many (new) daily situations occurring around the world. From this point of view, the dominant perspective from the Global North proceeds along analytical pathways that incorporate the Global South.

\section{In Which Direction Is the Study of Rural Spaces Heading? From Individualization to Global}

Rurality, as a structured axis of rural studies, has entered a relatively exhausted phase on both sides of the Atlantic and this debate has been significantly eroded by rhetorical or circular arguments $[29,51]$. Analysis of rural spaces is linked to a complex system of axes, planes and social scales in permanent instability, which oppose the explanatory frameworks of large spaces. Multiple realities, identities, experiences and perspectives can coexist in one (rural) place in a fluent manner. Moreover, there is also renewed interest to clarify the global processes that influence rural areas. As mentioned previously, rural studies have reached a crossroads: a turning back or (re)materialization [1], or a move forwards, based on non-representational arguments and on emotional geographies [48].

In this context, it is possible to explore an analytical approach that has been barely used to date $[87,88]$ : the individual dimension of rural studies, linked to a post-modern view of the rural space that favors the individual-spatial relationship [89]. Traditionally, rural studies have been dominated by the community, such as the (local) world that integrates the rural life and its interaction with the natural and cultural (local) space and, more recently, as a (local) power structure [87]. From Tonnies [90] work, rural geography maintains the importance of the rural (homogeneous) community, which has obscured a detailed study inside the community, or of its individuals. Only recently, through moral perspectives [91] has there been a degree of integration of individual trajectories in rural studies, but without becoming detached from the traditional community perspective.

This new view of the individual has mainly an analytical and methodological component and is linked to a binary relationship that associates individual and globality, to compensate for the usual locality (community)-globality domain that has dominated and currently dominates rural studies. The rurality, traditionally defined from the political economy or from sociocultural approaches by the relationship of countryside-city and locality-globality, can be replaced by another type of (binary) relationship that transgresses rurality and rearticulates through the individual and the global.

An important component of this new panorama is: (a) analysis of binary relationships in the study of rurality through human, institutional, structural planes or even individual attributes; (b) a study of the realities or global areas not only as the opposite analytical pole to the individual, but also as a (re)articulated alternative of the social and economic processes constituted around the individual citizen, that moves in an area that behaves in an increasingly global manner. In other words, the countryside is articulated through multiple relationships where the rural-urban or local-global that usually defines the rurality constitutes just another binary relationship. The relationship that acquiring the greatest significance would, therefore, be that of the individual-global. This scenario has been partially sustained by Kay [92], who observed that, in times of globalization, the interaction and fluidity between the rural and urban has greatly increased in terms of capital, commodities and employment. In this way, many homes can now construct their lives outside the urban-rural, farming-non-farming and even outside national borders. Hence, (rural) places are rearticulated permanently as a consequence of a daily (re)negotiation 
between individuals, as Massey [93] explains, in order to construct living spaces where multiple individual trajectories converge. In this perspective, we can still find the meeting point that has appeared in analysis of the rural community since the political economy approach [25]. However, it also incorporates a new postmodern view of the individual and the space, which has significantly influenced (rural) geographical analysis, where places are constructed and maintained through individual daily experience, formed alone or in interaction with others [94].

Here, it is important to stop and reflect on the rural community. Previously, we suggested that the rural community coincided with the locality and the place, from a perspective of the political economy. This has resulted in restructuring processes being analyzed at a local or community level, homogeneously. The rural community itself is usually envisaged as an aggregate that has culturally common responses, not only to collective issues but also to more personal ones. These types of community perspectives could also be reviewed from the individual perspective, from a more moral standpoint, where different individuals from the same community could have different views on processes and adopt individual positions in the decision-making process. This would entail placing more emphasis on the individual in power relations, in the relationship with the environment and intracommunity relations. One could acknowledge the existence of different collective or community identities, from greater to less importance, that have different links to the place, and a series of moral lives that identify different interests, perspectives and even individual lifestyles, all in the form of a permanent and unstable equilibrium. This does not diminish the capacity of resistance to global processes-in the form of solidarity networks-which have usually been assigned to the community [17]. It actually reinforces it, by democratizing it and giving it a flexible and fluid dimension in relation to the local (sociopolitical) sphere, and to the place (the surroundings and management of space), both in relation to other communities, and to the State and transnational processes.

To effectively introduce the individual dimension in the global field through the individual-global field, which replaces the global-local field that has played an important role in studies of the community or local rurality, it is important to place the individual in different planes characteristic of postmodern (rural) geography. Each plane is dominated by a relevant postmodern characteristic or (global) orientation, where each individual develops his (daily) life. The distinct orientation of each plane is incorporated in each individual by the difference established through the repetition of particular individual behaviors [95]. Each postmodern characteristic of a plane steers the lives of the individuals, generating distinct styles of individuality. Although this does not promote the convergence and close relations between individuals around a place (with borders). Each oriented plane does not, necessarily, cultivate the confluence and (socio-spatial) meeting of individuals. On the contrary, each (rural) individual establishes-or can establish-his own strategy in relation to each geographical postmodern global process. Currently, the (rural) individual (rural) would not find just one destiny in his life. This would take the emphasis off rurality as a central focus of study (Figure 1).

The most important planes to analyze (rural) spaces would be the:

Ethnic plane: This is often defined in the literature by incorporation of the multicultural and cosmopolitan society in the description of the rurality. Hence, the introduction of perspectives often considered as minority, such as the introduction of indigenous angles, greatly helps to enrich the identity of the rural life, of its old stereotypes and its modern identities. With the ethnic plane, the relationship of individual-nature and its incidence can be incorporated in the use of resources, in addition to processes of community differentiation in many rural areas, governed by complex and multiethnic situations, which combine multiple hierarchical identities [96]. If we consider rurality as multiple aggregate identities where the citizen or cosmopolitan individual can be placed, the ethnic plane includes a new dimension of hybridization in the consideration of the rurality and is a clear rethinking of the relationships locals-self (community)-others or, more frequently, locals-others. 

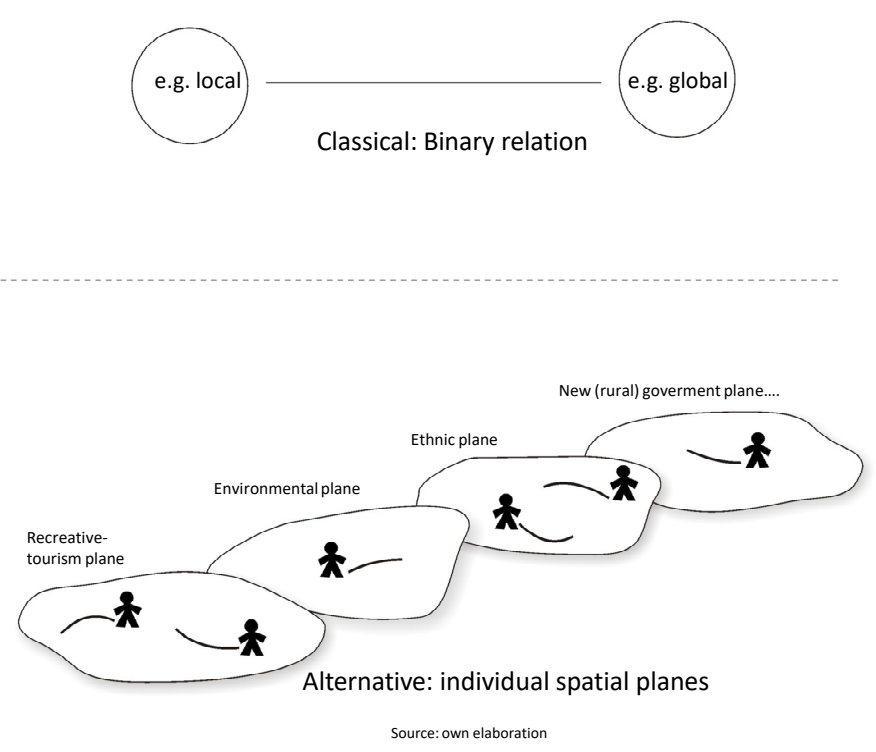

Figure 1. Classical and alternative.

Environmental plane: This has a multidimensional character, but two main approaches can be distinguished: on the one hand the relationship of society-nature and, on the other, the relationship of nature-culture (both binomial approaches in themselves) and also, the rural idyll-the idealized attraction of the countryside by urban populations. This is a complex angle, given that it ultimately refers to individual representations or the aggregation of individual identities in the consideration of the rural environment and a perspective of individual rights in environmental management, in the context of renewed relationships of society-nature [11]. In this context, it is possible to single out the relationship with the (rural) environment through daily practices and the relationship between human and non-human individuals [97].

Recreational-tourism plane: This is linked to the establishment of (rural) amenities to a renewed management of the material and non-material cultural-rural patrimony and to new recreational-tourism activities. Together, these all favor the separation of populations from their farming dedication and, in turn, help to attract different and cosmopolitan individuals to a (from a) global countryside. Different dynamics can be established that appear in a differentiated manner, such as: (1) national or international migration linked to the existence of amenities, cultural patrimony and recreational activities; (2) the establishment of amenities and tourism installations that promote a differentiation in employment and a functional transformation of the rural patrimony; (3) the revitalization of distant and cosmopolitan more regional or national rural identities. These dynamics are based on a degree of transformation from a view of production to a view of consumption in the rural spaces, which does not occur uniformly but confers the individual new economic and social practices.

Plane linked to new (rural) governance: This is differentiated from a traditional farming government [68], where the focus of interest is no longer the traditional farm but instead the individual who lives in a (rural) space, the individual as associated with the concept of citizen [98]. In the rural environment, people are subject to politics as producers and as citizens. This gives the individual a degree of autonomy and singularity and separates him from an option of (rural) development, which has helped to undermine the rural (citizen) individual compared to the urban (citizen) individual. This new rural government would also have a point of focus at the interphase between the State-local interests, which have often been considered to be conflictive. The local government would act as the mediator between the individual actors and the context (of greater or lesser size) [99]. 


\section{Conclusions}

In this paper, we have provided an overview of the numerous studies that have adopted rurality as a study focus, to reveal its limitations as an explanatory framework today. We, therefore, propose a new approach: the "individual-global field" along the way suggested by Cloke [1] and Woods [3] from a more flexible, positional everyday perspective in studies of rural geography. This proposal could be applied to rural studies of social orientation, many of which are inspired by social rural geography, or by contributions from its key figures. In fact, some of the studies mentioned here result from a joint effort with sociologists or social academics, with a shared theoretical approach (and limitations) [80].

This work does not provide an alternative to the role of the rural community as a closed entity between society, nature and space, governed to a large extent by the local-global perspective [3]. Nor does it suggest that a social category or level is no longer relevant or a complex breach within the (un)differentiated social by means of the individual. It does, however, extend the study perspective, which now has two new extremes: the individual and the global countryside that may or may not be mediated by the community. In any case, it suggests an acceptance of the individual as a player and an active recipient in a global countryside, in different planes dominated by styles of individuality, including the ethnic, environmental, recreational-touristic and the (rural) government. Through these, we suggest the different position of the (rural) individual in different contexts, which have been the focus of study for the analysts of processes of change and the new rurality. This approach would allow: (1) the possibilities of ethical and moral approaches and processes of modernity to be articulated; (2) a common theoretical umbrella to cover the new (rural) processes that emerge in different geographical areas. We, therefore, do not consider the individual as a player who moves freely $[93,100]$ throughout the (rural) space, but we do acknowledge the existence of rigid structures, which would be conditioning, but not limiting, in the individual-global binomial relationship.

At present, rural geography still reflects various trends. On the one hand, some works claim (re)materiality [50] based on: the value of rural heritage with a new value and use in another temporal and socioeconomic context; a revaluation of the rural house as an attraction for new populations and rural tourism. On the other hand, some works claim the awakening of non-representational theories in rural geography [49]. Other works of a more social nature insist on the global-rural negotiation of globalization and diversity in rural localities [32,100]. Other options show the different paths of rurality in urban settings and in the countryside [101], in this sense all the paths remain open in rural geography. In this context, it would be necessary to articulate a more-than-rural geography on the basis of the behavior of the rural individual that would allow synthesizing trends and articulating urban and rural spaces where social difference, beyond its size of populations, in many occasions is not the most relevant. The life of rural individuals moves in (rural) settings dominated by socio-economic contexts oriented towards production, consumption or life. All can be (re)articulated under the minor theory that dominates the analysis of the daily life of the rural individual. The individual and his differentiated projection in the globality can constitute a rich way of study for the progress of rural geography.

Funding: This research received no external funding.

Institutional Review Board Statement: Not Applicable.

Informed Consent Statement: Not Applicable.

Data Availability Statement: Not Applicable.

Conflicts of Interest: The authors declare no conflict of interest.

\section{References}

1. Cloke, P. Conceptualizing rurality. In Handbook of rural Studies; Cloke, P., Marsden, T., Mooner, P., Eds.; Sage: London, UK, 2006; pp. 18-28.

2. Woods, M. Rural geography: Blurring boundaries and making connections. Prog. Hum. Geogr. 2009, 33, 849-858. [CrossRef] 
3. Woods, M. Performing rurality and practising rural geography. Prog. Hum. Geogr. 2010, 34, 835-846. [CrossRef]

4. Robinson, G. Conflict and Change in the Countryside; Belhaven: London, UK, 1990.

5. Woods, M. Engaging the global countryside: Globalization, hybridity and the reconstitution of rural place. Prog. Hum. Geogr. 2007, 31, 485-507. [CrossRef]

6. McCarthy, J. Rural geography: Multifunctional rural geographies-Reactionary or radical? Prog. Hum. Geogr. 2005, 29, 773-782. [CrossRef]

7. Woods, M. Rural geography III: Rural futures and the future of rural geography. Prog. Hum. Geogr. 2012, 36, 125-134. [CrossRef]

8. Zoomers, A. Globalisation and the foreignisation of space: Seven processes driving the current global land grab. J. Peasant Stud. 2010, 37, 429-447. [CrossRef]

9. Cid Aguayo, B.E. Global villages and rural cosmopolitanism: Exploring global ruralities. Globalizations 2008, 5, 541-554. [CrossRef]

10. McDonagh, J. Rural geography I: Changing expectations and contradictions in the rural. Prog. Hum. Geogr. 2012, 37, 712-720. [CrossRef]

11. Whatmore, S. Hybrid geographies: Rethinking the 'human' in Human Geography. In Human Geography Today; Massey, D., Allen, J., Sarre, P., Eds.; Polity Press: Cambridge, UK, 2001; pp. 22-39.

12. Santos-Granero, F. Hybrid bodyscapes. A visual history of Yanesha Patterns of Cultural change. Curr. Antropol. 2009, 50, 477-512. [CrossRef]

13. Knox, P.L. Urban Social Geography: An Introduction; Harlow: Longman, UK, 1987.

14. Johnston, R. City and Society: An Outline for Urban Geography; Hutchinson: London, UK, 1984.

15. Lowe, P.; Murdoch, J.; Marsden, T.; Munton, R.; Flynn, A. Regulating the new rural spaces: The uneven development of land. J. Rural Stud. 1993, 9, 205-222. [CrossRef]

16. Marsden, T. Rural geography trend report: The social and political bases of rural restructuring. Prog. Hum. Geogr. 1996, 20, 246-258. [CrossRef]

17. Woods, M. The local politics of the global countryside: Boosterism, aspirational ruralism and the contested reconstitution of Queenstown, New Zealand. GeoJournal 2011, 76, 365-381. [CrossRef]

18. Murdoch, J.; Lowe, P.; Ward, N.; Marsden, T. The Differentiated Countryside; Routledge: London, UK, 2003.

19. Clout, H. Rural Geography; Pergamon Press: London, UK, 1972.

20. Hoggart, K.; Paniagua, Á. What rural restructuring? J. Rural Stud. 2001, 17, 41-62. [CrossRef]

21. Smith, N. Uneven Development. Nature, Capital and the Production of Space; Basil Blackwell: Oxford, UK, 1984.

22. Marsden, T.; Murdoch, J.; Willians, S. Regulating agricultures in deregulating economies: Emerging trends in the uneven development of agriculture. Geoforum 1992, 23, 333-345. [CrossRef]

23. Marsden, T. Exploring political economy approaches in agriculture. Area 1988, 20, 315-322.

24. Ilbery, B. (Ed.) The Geography of Rural Change; Longman: London, UK, 1998.

25. Marsden, T.; Murdoch, J.; Lowe, P.; Munton, R.; Flynn, A. Constructing the Countryside; UCL Press: London, UK, 1993.

26. Newby, H. Locality and rurality: The restructuring of rural social relations. Reg. Stud. 1986, 20, 209-215. [CrossRef]

27. Hoggart, K. Not a definition of Rural. Area 1988, 20, 35-40.

28. Hoggart, K. Let's do away with the rural. J. Rural Stud. 1990, 6, 245-257. [CrossRef]

29. Woods, M. Rural Geography; Sage: London, UK, 2005.

30. Kausky, K. The Agrarian Question; Zwan Publ.: London, UK, 1988; original 1899.

31. Gilg, A. Restructuring the countryside: An introductory essay. In Restructuring the Countryside: Environmental Policy in Practice; Gilg, A., Ed.; Avebury: Aldershot, UK, 1992; pp. 3-18.

32. Woods, M. Precarious rural consmopolitanism: Negotiating globalization, migration and diversity in Irish small towns. J. Rural Stud. 2018, 64, 164-176. [CrossRef]

33. Nelson, L.; Nelson, P. The global rural: Gentrification and linked migration in the rural USA. Prog. Hum. Geogr. 2010, 35, 441-459. [CrossRef]

34. McCarthy, J. Rural geography: Globalizing the countryside. Prog. Hum. Geogr. 2008, 32, 129-137. [CrossRef]

35. Brogger, D. Urban diáspora space: Rural-urban migration and the production of unequal urban spaces. Geoforum 2019, 102, 97-105. [CrossRef]

36. Cloke, P.; Thrift, N. Introduction: Refiguring the 'Rural'. In Writing the Rural: Five Cultural Geographies; Cloke, P., Doel, M., Matless, D., Phillips, M., Thrift, N., Eds.; Paul Chapman Pub.: London, UK, 1994; pp. 1-6.

37. Cloke, P.; Little, J. (Eds.) Contested Countryside Cultures: Otherness, Marginalisation and Rurality; Routledge: London, UK, 1997.

38. Cloke, P.; Doel, M.; Matless, D.; Phillips, M.; Thrift, N. Writing the Rural: Five Cultural Geographies; Paul Chapman Pub.: London, UK, 1994.

39. Halfacree, K. Locality and social representation: Space, discourse and alternative definitions of the rural. J. Rural Stud. 1993, 9 , 23-37. [CrossRef]

40. Little, J. Otherness, representation and the cultural construction of rurality. Prog. Hum. Geogr. 1999, 23, 437-442. [CrossRef]

41. Jones, O. Lay discourses of the rural: Developments and implications for rural studies. J. Rural Stud. 1995, 11, 35-49. [CrossRef]

42. Cloke, P.; Milbourne, P. Deprivation and lifestyles in rural Wales: Rurality and the cultural dimension. J. Rural Stud. 1992, 8, 359-371. [CrossRef]

43. Bunce, M. Reproducing rural idylls. In Country Visions; Cloke, P., Ed.; Pearson: Harlow, UK, 2003; pp. 14-30. 
44. Nelson, P. Rural restructuring in the American West: Land use, family and class discourses. J. Rural Stud. 2001, 17, 395-407. [CrossRef]

45. Frisvoll, S. Power in the production of spaces transformed by rural tourism. J. Rural Stud. 2012, 28, 447-457. [CrossRef]

46. Halfacree, K. Rural space: Constructing a three-fold architecture. In Handbook of Rural Studies; Cloke, P., Marsden, T., Mooney, P., Eds.; Sage: London, UK, 2006; pp. 44-62.

47. Phillips, M. The restructuring of social imaginations in rural Geography. J. Rural Stud. 1998, 14, 121-153. [CrossRef]

48. Holloway, L.; Kneafsey, M. Geographies of rural cultures and societies: Introduction. In Geographies of Rural Cultures and Societies; Holloway, L., Kneafsey, M., Eds.; Ashgate: London, UK, 2004; pp. 1-14.

49. Maclaren, A.S. Rural geographies in the wake of non-representational theories. Geogr. Compass 2019, 13, e12446. [CrossRef]

50. Lu, Y.; Qian, J. Towrds a material approach in rural geography: Arcritectural experiments in China's rural renaissance and reconstruction movements. Geoforum 2020, 116, 119-129. [CrossRef]

51. Woods, M. Rural; Routledg: London, UK, 2010.

52. Little, J. Rural (book review). Prog. Hum. Geogr. 2013, 37, 321-323. [CrossRef]

53. Gutierrez de MacGregor, M.T.; González, J. Propuesta para fijar diez mil habitantes como límite de una localidad urbana. Investig. Geográficas 2001, 44, 103-118. [CrossRef]

54. González, S.; Larralde, A. Conceptualización y medición de lo rural. Una propuesta para clasificar el espacio rural en México. In La Situación Demográfica de México 2013; CONAPO: Ciudad de México, México, 2013; pp. 141-157.

55. Llambí, L. Nueva ruralidad y multifuncionalidad de los espacios rurales. In Desarrollo Rural y Nueva Ruralidad en América Latina y la Unión Europea; Pérez, E., Adelaida Farah, M., Eds.; Pontificia Universidad Javeriana: Bogotá, Colombia, 2004 ; pp. 91-101.

56. Llambí, L. Reestructuraciones rurales y globalización. El debate entre economía política y postmodernismo en la sociología rural. Agric. Y Soc. 1997, 84, 325-346.

57. Pérez, E. Hacia una visión de lo rural. In ¿Una Nueva Ruralidad en América Latina? Giarracca, N., Ed.; CLACSO: Buenos Aires, Argentina, 2001; pp. 17-30.

58. Pérez, E. Lo rural y el desarrollo en América Latina. In Espacios y Desarrollos Rurales. Una Visión Múltiple Desde Europa y América Latina; Rodríguez, R., Pérez, E., Eds.; Trea: Oviedo, Spain, 2004; pp. 49-66.

59. Grammont, H. Introducción. In Globalización, Deterioro Ambiental y Reorganización Social en el Campo; Grammont, H., Ed.; UNAM: Ciudad de México, México, 1995; pp. 9-15.

60. Ramirez, J.; Tulet, C. Recomposición Territorial de la Agricultura Campesina en América Latina; Plaza y Valdés: Ciudad de México, México, 2011.

61. Akran-Lodhi, H.; Kay, C. Surveying the agrarian question (part 2): Current debates and beyond. J. Peasant Stud. 2010, 37, 255-284. [CrossRef]

62. Fox, J.; García Jiménez, C.; Haight, L. Rural democratisation in Mexico's deep south: Grassroots right-to-know campaigns in Guerrero. J. Peasant Stud. 2009, 36, 271-298. [CrossRef]

63. Otero, G. ¿Adiós al Campesinado?: Democracia y Formación Política de las Clases en el México Rural; Universidad Autónoma de Zacatecas: Zacatecas, México, 2004.

64. Wittman, H. Reworking the metabolic rift: La Vía Campesina, agrarian citizenship, and food sovereignty. J. Peasant Stud. 2009, 36, 805-826. [CrossRef]

65. Grammont, H. Introducción: Algunos ejes de reflexión sobre la construcción de la democracia en el campo latinoamericano. In La Construcción de la Democracia en el Campo Latinoamericano; Grammont, H., Ed.; CLACSO: Buenos Aires, Argentina, 2006; pp. 9-22.

66. Woods, M. Social movements and rural politics. J. Rural Stud. 2008, 24, 129-137. [CrossRef]

67. Gudeman, S. Relationships, Residence and the Individual: A Rural Panamanian Community; Routledge: London, UK, 2004.

68. Kay, C. Development strategies and rural development: Exploring synergies, eradicating poverty. J. Peasant Stud. 2009, 36, 103-138. [CrossRef]

69. Pérez Sainz, J.P.; Andrade Eekhoff, K. Communities in Globalization: The invisible Mayan Nahual; Rowman and Littlefield: Oxford, UK, 2003.

70. Glockner Fagetti, V. De la Montaña a la Frontera: Identidad, Representaciones Sociales y Migración de los Niños Mixtecos de Guerrero; El Colegio de Michoacán: Zamora, México, 2008.

71. Wilson, F. Mobility and territorializing regimes in the Andes. In Space Odysseys. Spatiality and Social Relations in the 21st Century; Ashgate: Aldershot, UK, 2004; pp. 135-152.

72. López, R.; Valdés, A. (Eds.) Rural Poverty in Latin America; MacMillan Press: London, UK, 2000.

73. Matarrita-Cascante, D.; Stocks, G. Amenity migration to the global south: Implications for community development. Geoforum 2013, 49, 91-102. [CrossRef]

74. Wood, C.; Bryan, R. (Eds.) Rethinking Development in Latin America; Pennsylvania University Press: Philadelphia, PA, USA, 2005.

75. Escobar, A. Latin America at a crossroads. Cult. Stud. 2010, 24, 1-65. [CrossRef]

76. Gómez, S. Nueva ruralidad. Fundamentos teóricos y necesidad de avances empíricos. In La Nueva Ruralidad en América Latina. Avances Teóricos y Evidencias Empíricas; Pérez, E., Adelaida Farah, M., Grammont, H., Eds.; CLACSO—Pontificia Universidad Javeriana: Bogotá, Colombia, 2008; pp. 45-78.

77. Palafox, A.; Martínez, M.G. Turismo y nueva ruralidad: Camino a la sustentabilidad social. Let. Verdes Rev. Latinoam. Estud. Socioambient. 2015, 18, 137-158. 
78. Bendini, M. Actores sociales y reestructuraciones en los ámbitos rurales y agrarios de América Latina. In La Nueva Ruralidad en América Latina. Avances Teóricos y Evidencias Empíricas; Pérez, E., Adelaida Farah, M., Grammont, H., Eds.; CLACSO-Pontifica Universidad Javeriana: Bogotá, Colombia, 2008; pp. 133-150.

79. Riella, A.; Mascheroni, P. Evidencias empíricas sobre la pertenencia de la nueva ruralidad en Uruguay. In La Nueva Ruralidad en América Latina. Avances Teóricos y Evidencias Empíricas; Pérez, E., Adelaida Farah, M., Grammont, H., Eds.; Clacso-Pontificia Universidad Javeriana: Bogotá, Colombia, 2008; pp. 151-157.

80. Sanchez, M.; Canabal, B. (Eds.) Introducción. In La Encrucijada del México Rural. Contrastes Regionales en un Mundo Desigual. TomoIV. Migración, Trabajo y Relaciones de Género. La Vida en México y en Estados Unidos; Asociación Mexicana de Estudios Rurales: México, 2011; pp. 13-26.

81. Giarraca, N. Introducción. América Latina, nuevas ruralidades, viejas y nuevas acciones colectivas. In Ruralidades Latinoamericanas. Identidades y Luchas Sociales; Giarraca, N., Levy, B., Eds.; CLACSO: Buenos Aires, Argentina, 2004; pp. $13-43$.

82. Rodríguez Castro, L.; Pini, B.; Baker, S. The global countryside: Peasant women negotiating, recalibrating and resisting rural change in Colombia. Gend. Place Cult. 2016, 23, 1547-1559.

83. Paredes, W. La Fractura Campo-Ciudad y los Montubios (Desencuentros con la Ruralidad e Indiferencia Hacia los Montubios); Banco Central de Ecuador-Archivo histórico de Guayas: Guayaquil, Ecuador, 2009.

84. Salas, H.J.; Rivermar, L.; Velasco, P. (Eds.) Nuevas Ruralidades. Expresiones de la Transformación Social en México; Ed. Mariela: México, 2012.

85. Haar, G.; Reyes, M.E.; Moguel, R. Introducción: Vislumbrando procesos emergentes en el campo chiapaneco. In Espacios Disputados. Transformaciones Rurales en Chiapas; Reyes, M.E., Moguel, R., Haar, G., Eds.; UAM: México, 1998 ; pp. 9-18.

86. Grammont, H. El concepto de nueva ruralidad. In La Nueva Ruralidad en América Latina. Avances Teóricos y Evidencias Empíricas; Pérez, E., Adelaida Farah, M., Grammont, H., Eds.; CLACSO-Pontificia Universidad Javeriana: Bogotá, Colombia, 2008; pp. 23-44.

87. Gardner, G. (Re) positioning power in rural Studies: From organic community to political society. In Geographies of Rural Cultures and Societies; Holloway, L., Kneafsey, M., Eds.; Ahsgate: London, UK, 2004; pp. 55-78.

88. Carolan, M.S. More than representational knowledge/s of the countryside: How we think as bodies. Sociol. Rural. 2008, 48, 408-422. [CrossRef]

89. Valentine, G.; Hughes, K.A. Shared space/distant lives? Understanding the meaning of personal relationships, family and intimacy at home through the lens of internet gambling. Trans. Inst. Br. Geogr. 2012, 37, 242-255. [CrossRef]

90. Tonnies, F. Community and Association; Routledge \& Kegan Paul.: London, UK, 1957; original 1887.

91. Cloke, P. Deliver us from evil? Prospects for living ethically and acting politically in Human Geography. Prog. Hum. Geogr. 2002, 26, 587-604. [CrossRef]

92. Kay, C. Las políticas agrarias en Europa y América Latina. In Desarrollo Rural y Nueva Ruralidad en América Latina y la Unión Europea; Pérez, E., Adelaida Farah, M., Eds.; Pontificia Universidad Javeriana: Bogotá, Colombia, 2004; pp. 81-90.

93. Massey, D. For Space; Sage: London, UK, 2005.

94. Cresswell, T. Individual place. In The Companion Encyclopedia of Geography; Huggart, R., Douglas, I., Perkins, C., Eds.; Routledge: London, UK, 2007; pp. 31-41.

95. Deleuze, G. Difference and Repetition; Columbia University Press: New York, NY, USA, 1994; original 1968.

96. Ramirez, A. Desarrollo Humano en Chile Rural. Seis Millones por Nuevos Caminos; Programa de la Naciones Unidas para el Desarrollo: Santiago, Chile, 2008.

97. Buller, H. Individuation, the mass and farm animals. Theory Cult. Soc. 2013, 30, 155-175. [CrossRef]

98. Parker, G. Citizenships, Contingency and the Countryside. Rights, Culture, land and the Environment; Routledge: London, UK, 2001.

99. Rose, N. The death of the social? Refiguring the territory of government. Econ. Soc. 1996, 25, 327-356. [CrossRef]

100. Webster, N.A. Rural-to-rural translocal practices: Thai women entrepreneurs in the Swedish countryside. J. Rural Stud. 2017, 56, 219-228. [CrossRef]

101. Paniagua, A. Geographies of Differences (and Resistances) in Urbanized and Depopulated Remote Rural Areas; Springer: Cham, Switzerland, 2020. [CrossRef] 